JIPSINDO (Jurnal Pendidikan Ilmu Pengetahuan Sosial Indonesia)

ISSN: 2355-0139 (p); 2615-7594 (e)

Vol. 8. No. 1 (2021), 89-103, doi: https://doi.org/10.21831/jipsindo.v8i1.39185

\title{
Pembentukan karakter melalui outdoor learning dalam pembelajaran IPS
}

\author{
Oleh: \\ Yuhanida Milhani \\ Universitas Negeri Yogyakarta \\ yuhanida@uny.ac.id \\ received:04-03-2021 revised: 23-03-2021 accepted:23-03-2021
}

\begin{abstract}
Abstrak
Tujuan penelitian adalah mengetahui bagaimana pembentukan karakter melalui outdoor learning dalam pembelajaran IPS SMP. Metode yang dingunakan yaitu penelitian kualitatif. Penelitian dilakukan di SMP Tumbuh Yogyakarta. Data diperoleh dari hasil indept interview dengan key informan: kepala sekolah, para wakil kepala sekolah, wali kelas, guru, dan siswa. Data dianalisis dengan menggunakan langkah-langkah: data reduction, data display, dan conclusion/verification). Berdasarkan hasil penelitian dapat disimpulkan: 1) Pembentukan karakter dapat dibagi menjadi dua strategi , yaitu internal dan eksternal sekolah; 2) strategi internal sekolah dapat ditempuh melalui empat pilar, yakni kegiatan belajar mengajar di kelas dengan metode pembelajaran yang telah disiapkan, kegiatan keseharian dalam bentuk school culture, kegiatan habituation, kegiatan kokurikuler, dan ekstra kurikuler; dan 3) strategi eksternal dapat ditempuh melalui kerja sama dengan orang tua dan masyarakat.
\end{abstract}

Kata kunci: pendidikan karakter, outdoor learning, IPS

\begin{abstract}
The purpose of this study was to determine how character formation through outdoor learning in junior high school social studies learning. The method used is qualitative research. The research was conducted at SMP Tumbuh Yogyakarta. Data obtained from the results of indept interviews with key informants: school principals, vice principals, homeroom teachers, teachers, and students. Data were analyzed using the following steps: data reduction, display data, and conclusion/verification). Based on the research results, it can be concluded that: (1) Character building can be divided into two strategies, namely internal and external schools; (2) the school's internal strategy can be pursued through four pillars, namely teaching and learning activities in class with prepared learning methods, daily activities in the form of school culture, habituation activities, co-curricular activities, and extra-curricular activities; and (3) external strategies can be pursued in collaboration with parents and the community. Keywords: character education, outdoor learning, social studies
\end{abstract}




\section{Pendahuluan}

Dewasa ini permasalahan yang dihadapi oleh bangsa Indonesia semakin kompleks, hal ini dapat kita lihat dari munculnya berbagai permasalahan sosial yang melanda masyarakat kita seperti kekerasan, ketidakjujuran, keserakahan, perpecahan keluarga, kasus korupsi, perebutan kekuasaan, kenakalan remaja, kasus narkoba, seks bebas, tawuran, fenomena geng motor, meningkatnya kriminalitas, kasus bullying yang menunjukkan terjadinya pergeseran nilai yang ada dalam masyarakat. Selain itu yang tidak dapat kita pungkiri adalah semakin lunturnya nilai nilai karakter pada generasi muda saat ini ditandai dengan semakin banyaknya kasus siswa yang melakukan kekerasan terhadap guru, perilaku hate speech, perilaku remaja yang cenderung cuek dan kurang sopan dan masih banyak permasalahan moral dan karakter yang melanda masyarakat kita. Beberapa waktu belakangan ini dunia pemberitaan dihebohkan oleh pemberitaan seorang murid yang menantang gurunya saat ia diingatkan oleh gurunya sedang merokok. Video yang viral tersebut nampak seorang siswa memegang kerah gurunya sambil merokok dan melempar kata-kata yang tidak sopan. Dalam kelas itu nampak begitu ribut dan siswa yang merokok sambil duduk di meja. Kasus tersebut terjadi di salah satu SMP swasta di Kabupaten Gresik. Akhirnya kasus selesai dengan damai karena sang guru memaafkan siswa tersebut. Kasus ini merupakan tamparan keras bagi pendidikan Indonesia yang notabene saat ini sedang digembor-gemborkan pendidikan karakter yang dinaungi dengan Permendikbud No. 20 Tahun 2018. Dalam Permendikbud No. 20 tahun 2018 pasal 2 disebutkan bahwa PPPK dilaksanakan nilainilai pancasila dalam pendidikan karakter (Purnomo, 2019).

Dengan penguatan pendidikan karakter ini diharapkan dapat menanamkan karakter mulia bagi peserta didik melalui pendidikan lingkungan sekolah mengingat saat ini semakin lunturnya nilai-nilai karakter siswa. Kasus tantangan siswa kepada guru adalah contoh nyata merosotnya moral siswa di lingkungan sekolah. Kasus ini sebenarnya bukan kali pertama terjadi di Indonesia melainkan banyak juga kasus diluar sana yang tidak terekspos media. Tanpa penanganan yang benar benar serius, permasalahan permasalahan tersebut tentunya akan semakin mengikis karakter bangsa. 
Karakter bangsa adalah elemen penting yang menentukan kemajuan suatu bangsa, karena dengan karakter bangsa yang unggul akan menjadi pendorong dalam meningkatkan kualitas sumber daya manusia. Peningkatan kualitas sumber daya manusia dapat ditempuh melalui perbaikan sistem pendidikan yang mengarah pada pembentukan karakter siswa sejak tingkat pra sekolah sampai perguruan tinggi (Wulandari,dkk., 2015 :46) pembentukan karakter dilakukan sebagai upaya untuk meningkatkan perilaku individu secara berkesinambungan.

Pendidikan merupakan pilar tegaknya suatu bangsa, melalui pendidikan suatu bangsa akan tegak mampu menjaga martabatnya (Wibowo, dkk., 2016 : 2). Dalam proses ini pendidikan dimaknai sebagai proses pembentukan kepribadian dan pengembangan seseorang sebagai makhluk individu, sosial, susila, dan makhluk yang beragama. Kesemuanya menghendaki manusia menjadi makhluk yang seimbang sehingga diharapkan pendidikan dapat menyediakan proses untuk mencapai tujuan tersebut. Hal ini diperkuat dengan pendapat Lickona (1999) yang mengemukakan bahwa character education has three goals: good people, good schools, and a good society. Dalam kalimat tersebut mengandung pengertian bahwa tujuan pertama menegaskan bahwa kita membutuhkan karakter yang baik untuk menjadi manusia seutuhnya. Tujuan kedua menegaskan bahwa kita membutuhkan pendidikan karakter untuk memiliki sekolah yang baik. Sekolah jauh lebih kondusif untuk pengajaran dan pembelajaran. Tujuan ketiga menegaskan bahwa pendidikan karakter sangat penting untuk tugas membangun moral masyarakat. Masalah sosial, seperti kekerasan, ketidakjujuran, keserakahan, perpecahan keluarga.

Pendidikan karakter memiliki tiga fungsi utama. Pertama, fungsi pembentukan dan pengembangan potensi. Pendidikan karakter membentuk dan mengembangkan potensi siswa agar berpikiran baik, berhati baik, dan berperilaku sesuai dengan falsafah pancasila. Kedua, fungsi per baikan dan penguatan. Pendidikan karakter memperbaiki dan memperkuat peran keluarga, satuan pendidikan, masyarakat, dan pemerintah untuk ikut berpartisipasi dan bertanggung jawab dalam pengembangan potensi warga negara dan pembangunan bangsa menuju bangsa yang maju, mandiri, dan sejahtera. Ketiga, fungsi penyaring. Pendidikan karakter memilah budaya bangsa sendiri dan menyaring budaya bangsa lain yang tidak sesuai dengan nilai-nilai budaya bangsa dan karakter bangsa yang bermartabat (Zubaidi, 2011:18). 
Karakter berasal dari nilai tentang sesuatu. Suatu karakter akan melekat dengan nilai dari perilaku seseorang. Karena itu, dalam perspektif pendidikan karakter, tidak ada perilaku anak ya ng tidak bebas dari nilai (Kesuma, dkk., 2011:2). Nilai -nilai pendidikan karakter yang dikembangkan Kementerian Pendidikan dan Kebudayaan ada delapan belas karakter. Nilai -nilai tersebut bersumber dari agama, Pancasila, budaya, dan tujuan pendidikan nasional. Adapun delapan belas nilai tersebut yaitu: religius, jujur, toleransi, disiplin, kerja keras, kreatif, mandiri, demokratis, rasa ingin tahu, semangat kebangsaan, cinta tanah air, menghargai prestasi, bersahabat/ komunikatif, cinta damai, gemar membaca, peduli lingkungan, peduli sosial, dan tanggung jawab. Dilihat dari segi komponennya, pendidikan karakter lebih menekankan pen tingnya tiga komponen karakter yang baik (components of good character) yaitu moral knowing atau pengetahuan tentang moral, moral feeling atau perasaan tentang moral dan moral action atau perbuatan bermoral (Lickona, 1991:21).

Kesuma (2011: 2) berpendapat bahwa ada tiga desain pendidikan karakter. Pertama, desain pendidikan karakter berbasis kelas. Desain ini berbasis pada hubungan guru sebagai pendidik dan siswa sebagai pembelajar di dalam kelas. Konteks pendidikan karakter adalah proses hubungan komunitas kelas dalam konteks pembelajaran. Relasi antara guru dengan pembelajar bukan monolog, melainkan dialog dengan banyak arah. Kedua, desain pendidikan karakter berbasis kultur sekolah. Desain ini membangun budaya sekolah yang mampu membentuk karakter siswa dengan bantuan pranata sosial sekolah agar nilai tertentu terbentuk dalam diri siswa. Ketiga, desain pendidikan karakter berbasis komunitas. Dalam mendidik, komunitas sekolah negeri maupun swasta tidak berjuang sendirian. Kalau ketiga komponen bekerjasama melaksanakan dengan baik, maka akan terbentuk karakter bangsa yang kuat.

SMP Tumbuh Yogyakarta merupakan salah satu sekolah yang konsen terhadap pembentukan karakter siswa. SMP Tumbuh Yogyakarta merupakan bentuk keberlanjutan pendidikan inklusif dan multikultur dari Sekolah Tumbuh yang berada di bawah naungan Yayasan Edukasi Anak Nusantara (YEAN). SMP Tumbuh memberikan layanan pendidikan untuk jenjang Sekolah Menengah Pertama (SMP) dengan menerapkan semangat pendidikan untuk semua (education for all), menghargai dan menghormati perbedaan, tumbuh dalam keberagaman agama, ekonomi, budaya dan kebutuhan 
khusus. Anak-anak terus tumbuh dan berkembang, kebutuhan dan minat mereka pun berubah, bahkan potensi juga berkembang.

Sekolah Tumbuh yang konsisten menggerakkan roda pendidikan inklusi dan multikultur ingin terus melanjutkan semangat pendidikan untuk semua di jenjang pendidikan sekolah menengah agar semangat dan nilai-nilai yang sudah dipupuk di Sekolah Dasar dapat terus dikembangkan di sekolah menengah, untuk selanjutnya menjadi bagian hidup dan karakter warganya. Sejalan dengan visi SMP Tumbuh yaitu anak tumbuh dan berkembang sebagai pembelajar yang berkarakter, menghargai keberagaman, mencintai tanah air dan kearifan lokal, serta menunjukkan kesadaran sebagai warga dunia.

Ilmu Pengetahuan Sosial merupakan perpaduan cabang ilmu pengetahuan pada ilmu sosial dan konsep-konsep humaniora, dengan tujuan kemampuan praktik kewarganegaraan terhadap isu-isu sosial yang kritis. Tujuan utama Ilmu Pengetahuan Sosial adalah untuk mengembangkan potensi siswa agar mampu beradaptasi, peka terhadap masalah sosial yang terjadi di masyarakat, memiliki sikap mental positif terhadap perbaikan segala ketimpangan yang terjadi, dan terampil mengatasi setiap masalah yang terjadi sehari-hari baik yang menimpa dirinya sendiri maupun yang menimpa masyarakat. Sejalan dengan tujuan IPS tersebut maka pembentukan karakter peserta didik sangat relevan diintegrasikan dalam Pembelajaran IPS.

Berdasarkan latar belakang diatas peneliti tertarik untuk melakukan penelitian dengan tujuan penelitian untuk melihat bagaimana pembentukan karakter peserta didik melalui outdoor learning dalam pembelajaran IPS SMP, yang dalam hal ini penelitian difokuskan pada SMP Tumbuh Yogyakarta sebagai salah satu sekolah yang konsen dengan pendidikan karakter sesuai dengan visi sekolahnya yaitu anak tumbuh dan berkembang sebagai pembelajar yang berkarakter, menghargai keberagaman, mencintai tanah air dan kearifan lokal, serta menunjukkan kesadaran sebagai warga dunia.

\section{Metode Penelitian}

Pendekatan penelitian yang digunakan dalam penelitian ini adalah pendekatan kualitatif. Pendekatan ini menyajikan temuannya dalam bentuk deskripsi kalimat yang rinci lengkap, dan mendalam mengenai proses mengapa dan bagaimana sesuatu terjadi. Pengumpulan data dilakukan dengan menggunakan beberapa teknik yaitu: 1) teknik 
wawancara mendalam (in depth interviewing), dalam penelitian ini dilakukan dengan pertanyaan yang bersifat terbuka (open-ended) dan mengarah pada kedalaman informasi serta dilakukan tidak secara formal terstruktur guna menggali pandangan subjek yang diteliti tentang banyak hal yang sangat bermanfaat untuk menjadi dasar bagi penggalian informasi secara lebih jauh, lengkap, dan mendalam. 2) observasi, dilakukan untuk melihat bagaimana pembentukan karakter melalui outdoor learning dalam pembelajaran IPS. 3) analisis dokumen, sebagai pelengkap dari data yang dikumpulkan melalui wawancara.

Penelitian ini dilakukan di SMP Tumbuh Yogyakarta. Subjek penelitian ini adalah Kepala Sekolah, Guru dan peserta didik. Sumber data yang digunakan meliputi sumber data primer dan sumber daya sekunder. Setelah data terkumpul dianalisis dengan menggunakan teknik induktif (Bog- dan dan Biklen, 1998) yang menempuh langkah langkah: reduksi data (data reduction), penyajian data (data display), dan verifikasi data (conclusion drawing/verification).

\section{Hasil dan Pembahasan}

SMP Tumbuh Yogyakarta merupakan bentuk keberlanjutan pendidikan inklusif dan multikultur dari Sekolah Tumbuh yang berada di bawah naungan Yayasan Edukasi Anak Nusantara (YEAN). SMP Tumbuh memberikan layanan pendidikan untuk jenjang Sekolah Menengah Pertama (SMP) dengan menerapkan semangat pendidikan untuk semua (education for all), menghargai dan menghormati perbedaan, tumbuh dalam keberagaman agama, ekonomi, budaya dan kebutuhan khusus.

Anak-anak terus tumbuh dan berkembang, kebutuhan dan minat mereka pun berubah, bahkan potensi juga berkembang. Sekolah Tumbuh yang konsisten menggerakkan roda pendidikan inklusi dan multikultur ingin terus melanjutkan semangat pendidikan untuk semua di jenjang pendidikan sekolah menengah agar semangat dan nilai-nilai yang sudah dipupuk di Sekolah Dasar dapat terus dikembangkan di Sekolah Menengah, untuk selanjutnya menjadi bagian hidup dan karakter warganya.

SMP Tumbuh memiliki visi yaitu anak tumbuh dan berkembang sebagai pembelajar yang berkarakter, menghargai keberagaman, mencintai tanah air dan kearifan lokal, serta menunjukkan kesadaran sebagai warga dunia. Untuk dapat mewujudkan visinya, maka Misi SMP Tumbuh antara lain sebagai berikut: 
Pembentukan karakter .... (Yuhanida Milhani)

1) Menyelenggarakan pendidikan inklusif yang mengembangkan anak sesuai potensi dan kebutuhan masing-masing.

2) Memberikan pembelajaran yang mendorong anak menghargai keragaman agama, ekonomi, dan budaya.

3) Memberikan pembelajaran yang mendorong anak menghargai kekayaan bangsa dan potensi lokal.

4) Memberikan pembelajaran yang menyiapkan anak sebagai warga dunia yang aktif dan berpikiran terbuka.

Berdasarkan hasil wawancara yang peneliti lakukan terdapat beberapa strategi ditempuh oleh SMP Tumbuh dalam upaya untuk membentuk karakter siswa. Pembentukan karakter dapat dibagi menjadi dua strategi, yaitu internal dan eksternal sekolah. Strategi internal sekolah dapat ditempuh melalui empat pilar, yakni kegiatan belajar mengajar di kelas dengan metode pembelajaran yang telah disiapkan, kegiatan keseharian dalam bentuk school culture, kegiatan habituation, kegiatan kokurikuler, dan ekstra kurikuler. Strategi eksternal dapat ditempuh melalui kerja sama dengan orang tua dan masyarakat.

Adapun Sasaran SMP Tumbuh Yogyakarta yaitu memfasilitasi siswa untuk menjadi hands on, mind on and heart on dalam setiap perubahan dunia dan menjadi bagian dari komunitas di dunia.

1. Hands on: Memfasilitasi dan mendorong anak untuk menjadi manusia pembelajar dan terus tertarik belajar secara antusias melalui pengalaman langsung.

2. Mind on: Mendorong anak untuk terus berpikir, memiliki rasa ingin tahu yang kuat, memecahkan persoalan, berpikir kritis dan tertantang untuk melakukan inovasi.

3. Heart on: Mendorong anak untuk menjadi lifelong-learner (pembelajar seumur hidup), reflektif dan memiliki kepekaan atas dunia yang terus berubah dan peduli lingkungan. 
Tabel 1

Metode pembelajaran yang digunakan di SMP Tumbuh Yogyakarta

\begin{tabular}{|c|c|c|}
\hline No & Metode Pembelajaran & Keterangan \\
\hline 1 & Inquiry Learning Approach & $\begin{array}{l}\text { proses kegiatan pembelajaran dari tuning in, } \\
\text { finding out, sorting out, going further, } \\
\text { reflecting and taking-action. }\end{array}$ \\
\hline 2 & Active Learning & $\begin{array}{l}\text { Bentuk pembelajaran yang memungkinkan } \\
\text { siswa berperan secara aktif dalam proses } \\
\text { pembelajaran itu sendiri baik dalam bentuk } \\
\text { interaksi antar siswa maupun antara siswa } \\
\text { dengan pengajar dalam proses pembelajaran } \\
\text { tersebut. }\end{array}$ \\
\hline 3 & Cooperative Learning & $\begin{array}{l}\text { Pembelajaran berbasis kerja sama } \\
\text { merupakan suatu strategi belajar mengajar } \\
\text { yang menekankan pada sikap atau perilaku } \\
\text { bersama (team working) dalam bekerja atau } \\
\text { membantu di antara sesama dalam struktur } \\
\text { kerjasama yang teratur dalam kelompok, } \\
\text { yang terdiri dari dua orang atau lebih. }\end{array}$ \\
\hline 4 & Differciative Learning & $\begin{array}{l}\text { Menerapkan strategi pembelajaran yang } \\
\text { merespon kebutuhan dan kemampuan siswa, } \\
\text { terutama untuk siswa yang berkebutuhan } \\
\text { khusus, gifted and talented, untuk } \\
\text { memberikan dan memfasilitasi proses } \\
\text { pembelajaran terbaik yang disesuaikan } \\
\text { dengan kondisi dan potensi peserta didik. }\end{array}$ \\
\hline 5 & $\begin{array}{l}\text { IDU (Interdisciplinary Unit } \\
\text { Programme) }\end{array}$ & $\begin{array}{l}\text { Program unit interdisipliner merupakan } \\
\text { sebuah program yang mengembangkan } \\
\text { pendekatan cara belajar dengan membangun } \\
\text { link atau hubungan antar mata pelajaran dan } \\
\text { bidang studi sehingga pembelajaran } \\
\text { berlangsung lebih bermakna dan } \\
\text { terintegrasi. }\end{array}$ \\
\hline
\end{tabular}

Sekolah Tumbuh percaya bahwa proses pendidikan yang bermakna melibatkan seluruh aspek diri sang pembelajar, lebih dari sekedar mempelajari mata pelajaran. Sekolah Tumbuh memberikan pengalaman belajar yang menyenangkan dan bermakna, baik bagi para siswa maupun guru, untuk menumbuhkan sikap-sikap positif yang akan terus melekat sebagai pembelajar sepanjang hayat. 
Tabel 2

Program Pendukung SMP Tumbuh Yogyakarta

\begin{tabular}{|c|c|c|}
\hline No & Program & Implementasi Program \\
\hline 1 & Orientation Days & $\begin{array}{l}\text { merupakan satu kegiatan orientasi bagi siswa } \\
\text { baru sebagai sarana pengenalan profil, } \\
\text { program, kegiatan, lingkungan dan warga } \\
\text { sekolah di SMP TUMBUH Kegiatan ini } \\
\text { dilaksanakan selama 2-3 hari di setiap awal } \\
\text { tahun ajaran. }\end{array}$ \\
\hline 2 & $\begin{array}{l}\text { Morning } \\
\text { Reflection }\end{array}$ & $\begin{array}{l}\text { \&orning Carpet merupakan suatu kesempatan } \\
\text { untuk memulai hari dengan berdoa dan } \\
\text { membagikan sesuatu yang dapat memberikan } \\
\text { pencerahan (insight). } \\
\text { Reflection adalah suatu kesempatan untuk } \\
\text { mengakhiri hari dengan berdoa dan } \\
\text { menceritakan refleksi/renungan. }\end{array}$ \\
\hline 3 & Kebijakan Literasi & $\begin{array}{l}\text { Implementasi literasi dalam semua mata } \\
\text { pelajaran sebagai bagian dari literacy skills, } \\
\text { termasuk di dalamnya keterampilan untuk } \\
\text { melakukan library research, menyusun } \\
\text { laporan dan bibliografi untuk menghindari } \\
\text { plagiarism. Literacy Time: waktu khusus bagi } \\
\text { siswa untuk membaca di kelas, dilaksanakan } \\
\text { setiap hari Selasa-Kamis, dengan pilihan } \\
\text { bacaan yang disukai, selama materi bacaan } \\
\text { sesuai dengan minat, usia, dan kemampuan } \\
\text { membaca, serta tidak mengandung pornografi, } \\
\text { kekerasan dan menyinggung isu SARA. }\end{array}$ \\
\hline & Area Pertumbuhan & $\begin{array}{l}\text { Area Pertumbuhan merupakan program khas } \\
\text { SMP TUMBUH yang menggeluti teman-tema } \\
\text { seputar pengenalan dan pengembangan } \\
\text { kepribadian dan keterampilan siswa }\end{array}$ \\
\hline 5 & Outing & $\begin{array}{l}\text { Secara berkala, sekolah mengadakan } \\
\text { kunjungan ke tempat-tempat yang bisa } \\
\text { menjadi sumber belajar anak. Melalui kegiatan } \\
\text { ini, para siswa diajak untuk mengalami } \\
\text { pembelajaran secara langsung dan } \\
\text { memperoleh informasi primer yang akan } \\
\text { memperkaya pengalaman belajarnya. } \\
\text { Perencanaan tentang outing disusun oleh } \\
\text { sekolah dan guru. }\end{array}$ \\
\hline
\end{tabular}


Outdoor learning yang dilaksanakan di SMP Tumbuh Yogyakarta merupakan Program pendidikan di luar kelas atau Education Outside The Classroom (EOTC) merupakan salah satu metode pembelajaran yang dinilai efektif dan efisien untuk lebih memahami materi pelajaran. EOTC memberikan kesempatan kepada siswa untuk menggali lebih dalam materi pembelajaran karena siswa tidak hanya memahami teori, tetapi langsung dihadapkan pada permasalahan.

Salah satu bentuk kegiatan outdoor learning yang SMP Tumbuh Yogyakarta yaitu kunjungan ke Joglo tani merupakan bagian dari program EOTC yang diintegrasikan ke dalam berbagai pelajaran antara lain: IPS, Bahasa Jawa Bahasa Indonesia, IPA, Bahasa Inggris, dan Matematika. Dengan integrasi ini diharapkan siswa dapat memahami mengenai pertanian terpadu dan segala hal yang terkait dengan pertanian baik dari aspek budaya, agama, sosial dll.

Tabel 3

Tujuan dan output dari Outing ke Joglo Tani

\begin{tabular}{lll}
\hline Tujuan & \multicolumn{2}{c}{ Output } \\
\hline Siswa belajar tentang pertanian terpadu dari & Siswa bertambah pemahaman \\
berbagai mata pelajaran. & mengenai pertanian terpadu dan \\
& segala hal yang terkait dengan \\
& pertanian baik dari aspek budaya, \\
& & agama, sosial dll \\
\hline Siswa belajar untuk meneliti, praktik dan & Laporan kegiatan/pembelajaran \\
mengamati tentang kegiatan pertanian terpadu di & yang dibuat oleh siswa sesuai \\
Joglo Tani & & dengan mata pelajaran yang terlibat \\
& kegiatan outing.
\end{tabular}

Joglo Tani adalah suatu gerakan pemberdayaan ekonomi sosial masyarakat yang di bangun oleh bapak TO Suprapto yang beralamat di Mandungan, Godean, Yogyakarta melalui Gerakan Pertanian Terpadu. Di dalam Joglo Tani terdapat beberapa komponen pertanian dan peternakan. Dan pengelolaannyapun sebagian besar di lakukan oleh masyarakat. Bervisi kemerdekaan dan bermisi kesejahteraan mendorong pak TO untuk bisa membangun 1500 Joglo Tani di seluruh Indonesia. Di 'Jogjo Tani', semua orang bisa belajar dan berbagi. Keterbukaan Suprapto dalam menerima pertanyaaan, akan 
membantu pengunjung dalam menghadapi masalah pertanian. Bidang kerja yang dilakukan Jogjo Tani antara lain: melakukan pendampingan, kemitraaan, dan kerjasama program. Memberikan pelatihan pertanian mandiri, wisata alam dan pedesaan, pelayanan jasa pertanian dan bisa digunakan sebagai laboratorium masyarakat.

Peserta adalah 32 Siswa kelas VII (kelas VII A dan VII B) Guru Pendamping adalah 8 guru yaitu: Bu Sari, Bu Nissa, Pak Fatrik, Bu Suharyanti, Bu Yuli, Pak Gading, Bu Adel \& Bu Riantina. Peserta outing beserta guru menggunakan transportasi bus untuk sampai pada lokasi. Dresscode siswa dan guru yaitu kaos Sekolah Tumbuh. Adapun Aturan selama mengikuti kegiatan outing:

1) Siswa wajib menghormati satu sama lain

2) Siswa tidak boleh melakukan tindakan bullying

3) Siswa wajib menjaga barang bawaannya masing-masing

4) Siswa tidak boleh membuat keributan selama kunjungan

5) Siswa wajib berperilaku sopan dan mengikuti aturan

6) Siswa wajib izin ke guru jika mau ke toilet

7) Siswa wajib mengikuti jadwal yang telah ditentukan

Kegiatan outdoor learning yang dilakukakan, pembentukan karakter tanggungjawab dan mandiri adalah karakter yang paling ditonjolkan dalam kegiatan tersebut. Hal ini dapat dilihat dari beberapa catatan yang harus diperhatikan oleh siswa yaitu Siswa wajib mengumpulkan tugas sesuai dengan penugasan pada mata pelajaran masing-masing sesuai dengan batas waktu yang telah ditentukan, serta Booklet tidak boleh hilang dan rusak, siswa wajib menjaga booklet dengan baik.

Dilihat dari beberapa hal tersebut artinya setelah mengikuti outdoor learning diharapkan karakter tanggungjawab pada diri siswa akan semakin baik. Strategi yang dikembangkan oleh SMP Tumbuh dalam upaya untuk membentuk karakter siswa diantaranya melalui empat pilar, yakni kegiatan belajar mengajar di kelas dengan metode pembelajaran yang telah disiapkan, kegiatan keseharian dalam bentuk school culture, kegiatan habituation, kegiatan kokurikuler, dan ekstra kurikuler. 
Tabel 4

Kompetensi Dasar (KD) dan Indikator Pencapaian Kompetensi (IPK)

\title{
Kompetensi Dasar \\ Indikator Pencapaian Kompetensi (IPK)
}

\begin{abstract}
Memahami konsep ruang (lokasi, distribusi, 3.1.1 Menjelaskan tentang hubungan potensi, iklim, bentuk muka bumi, geologis, antara agama, ekonomi, sosial, flora dan fauna) dan interaksi antar ruang di budaya dan pertanian.

Indonesia serta pengaruhnya terhadap kehidupan manusia dalam aspek ekonomi, sosial, budaya dan pendidikan.

3.1.2 Menjelaskan tentang potensi sumber daya alam di pertanian terpadu.
\end{abstract}

Menyajikan hasil telaah konsep ruang 4.1.1 Menyajikannya dalam bentuk (lokasi, distribusi, potensi, iklim, bentuk laporan muka bumi, geologis, flora dan fauna)

Setiap guru memberikan tugas masing masing disesuiakan dengan standar kompetensi dan kompetensi dasar masing masing. Untuk pembelajaran IPS siswa diminta mencari informasi terkait beberapa pertanyaan yang telah disiapkan, misalnya siswa diminta menyebutkan potensi sumber daya alam yang terdapat di Joglo Tani, bagaimana sistem pengairan yang terdapat di Joglo Tani, bagaimana hubungan pertanian dengan sistem kepercayaan/agama, bagaimana dampak pertanian bagi kehidupan ekonomi, dst. Selanjutnya siswa diminta untuk membuat laporan hasil pembelajaran dilapangan.

\section{Simpulan}

Berbagai upaya ditempuh oleh SMP Tumbuh dalam upaya untuk membentuk karakter siswa. Pembentukan karakter dapat dibagi menjadi dua strategi, yaitu internal dan eksternal sekolah. Strategi internal sekolah dapat ditempuh melalui empat pilar, yakni kegiatan belajar mengajar di kelas dengan metode pembelajaran yang telah disiapkan, kegiatan keseharian dalam bentuk school culture, kegiatan habituation, kegiatan kurikuler, dan ekstra kurikuler. Strategi eksternal dapat ditempuh melalui kerja sama dengan orang tua dan masyarakat.

Pembelajaran IPS dengan model out-door learning di SMP Tumbuh memberikan nuansa humanis yang menyenangkan bagi peserta didik dimana dapat menumbuhkan 
Pembentukan karakter .... (Yuhanida Milhani)

karakter positif. Kerjasama dan keakraban sesama siswa semakin tumbuh, hubungan dengan guru juga semakin akrab menyebabkan pendidikan karakter di sekolah tersebut dapat berjalan dengan baik.

\section{Referensi}

Bogdan, R., C, \& Biklen, S., K. (1998). Qualitatif research for education: An introduction to theory and methods. Aliyn and Bacon, Inc.

Kesuma, D. dkk., (2011). Pendidikan karakter: Kajian teori dan praktik di sekolah. PT. Remaja Rosdakarya.

Lickona, T. (1991). Educating for character: How our schools can teach respect and responsibility. Bantam Books.

Lickona, T. (1999). Character education: Seven crucial issues. Action in Teacher Education, 20(4), 77-84. https://doi.org/10.1080/01626620.1999.10462937

Purnomo, D. (2019). murid-menantang-guru-bukti-gagalnya-pendidikan-karakter https://www.kompasiana.com/donypurnomo/5c610caebde575270b7c8535/muridmenantang-guru-bukti-gagalnya-pendidikan-karakter, diakses 18 Maret 2021

Wibowo, S., Sudarsono, A., \& Sudrajat. (2016). Implementasi pendidikan karakter di SMP Negeri 2 Klaten dan Mts. Wahid Hasyim Yogyakarta. JIPSINDO, 3(1), 1-23. https://doi.org/10.21831/jipsindo.v3i1.9663

Wulandari, t., Wijayanti, A. T., \& Sudrajat. (2015). Muatan nilai-nilai karakter melalui permainan tradisional di PAUD Among Siwi, Panggungharjo, Sewon, Bantul. JIPSINDO, 2(1), 44-65. https://doi.org/10.21831/jipsindo.voio.4524

Undang-Undang Republik Indonesia Nomor 20 Tahun 2003 tentang Sistem Pendidikan Nasional.

Zubaedi . (2011) Desain pendidikan karakter konsepsi dan aplikasinya dalam lembaga pendidikan. Prenada Media Group 